\title{
PHYSIOLOGICAL AND COMPETITIVE CHARACTERISTICS OF PROFESSIONAL FEMALE FUTSAL PLAYERS
}

\author{
Tommy Apriantono ${ }^{1 \mathrm{ABC}}$, Samsul Bahri ${ }^{1 \mathrm{BC}}$, Sri Ihsani Indah ${ }^{1 \mathrm{BC}}$, Winata Bagus ${ }^{1 \mathrm{DE}}$ \\ ${ }^{1}$ Institut Teknologi Bandung \\ Authors' Contribution: A - Study design; B - Data collection; C - Statistical analysis; D - Manuscript Preparation; E - Funds Collection
}

Corresponding Author: Tommy Apriantono, E-mail: tommy@fa.itb.ac.id

Accepted for Publication: March 20, 2021

Published: March 25, 2021

DOI: $10.17309 /$ tmfv.2021.1.03

\begin{abstract}
The study purpose was to examine the anaerobic and aerobic performance and also determine the influence of the anaerobic performance on specific movements during a match-play.

Materials and methods. A total of 12 Indonesian professional female players from Bandung district female futsal club were recruited and enrolled to participate in this study. They were required to complete one familiarization and two experimental sessions. During the first session (laboratory test), all players performed a treadmill test to ascertain their maximum rate of oxygen consumption $\left(\mathrm{VO}_{2} \mathrm{max}\right)$ and a running-based anaerobic sprint test (RAST) to measure their anaerobic performance. For the second session (on-court test), the participants played a simulated match on the court. A training team of 5 experts carried out an investigation regarding each player's competitive performance per match. Furthermore, the blood lactate concentration and Rate of Perceived Exertion (RPE) were assessed in the pre- and posttest for both sessions, which were separated by a week to enable the players to recover.

Results. The results showed that there was no significant difference between the mean power (MP) and fatigue index (FI) $(\mathrm{p}=0.425, \mathrm{p}=0.938$, respectively) for anaerobic performance using Analysis of Variance (ANOVA), although, the MP and FI of team $\mathrm{C}$ was lower compared to A and B. Furthermore, the total number of failed passes and shot off target of team C was larger compared to B and A (for failed passes $=30$ vs 20 vs 25 , for shot off target 14 vs 13 vs 8 ). Conclusions. The results obtained indicate that there are strong associations between anaerobic capacity and explosive movements (shooting, tackling, heading and passing) among female futsal players.
\end{abstract}

Keywords: anaerobic performance, sprint test, shooting, team sports, technique, $\mathrm{VO}_{2} \mathrm{max}$.

\section{Introduction}

As a country consisting of 268,074,600 inhabitants, Indonesia is one of the countries that have improved in futsal enthusiasm (Chandra, 2013). According to the world's trend, its popularity increases each year and is played by millions of either gender worldwide (Beato, Coratella, Schena, \& Hulton, 2017). The match is played between two teams, with each consisting of one goalkeeper and four outfield players (winger, defender and pivot) (Ayala, Sainz de Baranda, De Ste Croix, \& Santonja, 2011). Furthermore, it is played for two periods of 20 minutes and mainly indoor, with pitch dimensions of 25-42 m long and $1525 \mathrm{~m}$ wide (Farhani et al., 2019). Interestingly, the game usually lasts $70-80 \%$ longer than the scheduled 40 minutes, due to possibilities given by the rules such as stoppages for injuries, medical attention, time-outs from both teams etc. (CF et al., 2011).

(C) Apriantono, T., Bahri, S., Ihsani Indah, Sri, Bagus, W., 2021.
Many studies are enthusiastic to investigate the physiological characteristic of futsal due to its increasing popularity (Barbero-Alvarez, Soto, Barbero-Alvarez, \& Granda-Vera, 2008; Barbero-Alvarez et al., 2015; Naser, Ali, \& Macadam, 2017). For example, Barbero-Álvarez et al. (2015) explained that it is an intermittent high-intensity strenuous sport which requires physical, technical and tactical exigencies on the players. In addition, previous studies observed that $85-90 \%$ of heart rate (HRmax) and $75 \%$ of $\mathrm{VO}_{2}$ max are the average intensity characteristics needed during a match-play (Naser et al., 2017). Another study also observed that sprinting performance is a decisive factor, which is needed in intermittent high-intensity characteristics sports such as futsal (BarberoAlvarez et al., 2008; Naser et al., 2017). This argument was arisen due to the fact that players spend 5 and $12 \%$ of the game time sprinting and performing high-intensity running (Sales et al., 2018).

During a futsal match, anaerobic processes play the biggest role in supplying energy, especially in the explo- 
sive movements such as ball kicking, tackling, heading and sprinting (Corrêa et al., 2016). Meanwhile, the aerobic system predominantly provides the energy needed for continuous alternation of high intensity during the match-play (Castagna, D’Ottavio, Vera, \& Álvarez, 2009). Therefore, the game requires a high aerobic fitness along with well-developed anaerobic pathways (Astagna, 2010; Corrêa et al., 2016). Although, previous studies successfully revealed the its physiological characteristics, scientific knowledge regarding the physiological characteristics of female futsal players is rather limited. Furthermore, studies investigating the influence of anaerobic processes on the performance of players during match-play are scarce.

This study was carried out with interest in a few previous studies which observed the physiological characteristics of female futsal players (Beato et al., 2017; Lago-Fuentes et al., 2018; Ramos-Campo, Rubio-Arias, Carrasco-Poyatos, \& Alcaraz, 2016). For example, Beato et al. (2017) reported that there was a decrease in performance in the second half compared to the first. Specifically, it was explained that there was a significant decrease in the total distance covered between the first and the second half. Although, these studies showed great discoveries for the decreased performance caused by low aerobic fitness among female futsal players, measurement of other performance analysis like shooting, tackling, heading and passing were lacking. Consequently, the effects of anaerobic processes on the performance of players during match-play remain unclear.

The study purpose was to examine the anaerobic and aerobic performance of Indonesian professional female futsal players and secondly, to determine the influence of the anaerobic process on specific movements such as shooting, tackling, heading and passing in the match-play. It was hypothesized that a low anaerobic performance among players would significantly decrease their performance in shooting, tackling, heading and passing. Furthermore, the discoveries of this study may be added to the scientific study that supports the use of physiological characteristics as a formula to determine training regimens used by coaches, sports scientists and female futsal players.

\section{Materials and methods}

\section{Study participants}

Twelve Indonesian professional female players from Bandung district female futsal club were recruited and enrolled to participate in this study. This was on the basis of the following criteria: they should have at least 5 years of experience in the game, involved in training of at least 8-10 sessions per week for approximately 60 minutes duration per session, participated in national and international female futsal tournaments. Participants on any anti-inflammatory or anti-oxidant drugs within 2 months prior to the initial testing or during the experimental period and had a history of musculoskeletal injury 3 months prior to the study began, were not included. Subsequently, the participants were classified based on their level of achievement. The Bandung district female futsal club has reached the runner up position in the National District Female Futsal Championship (PORDA West Java 2018). Therefore, they were classified as professional players. The study was carried out from 2-30 January
2019, which was two weeks after the PORDA West Java 2018 Championship and two months prior to West Java District Female National League 2019. All members of the committee were required to provide an explanation of the procedure, the risks that would later be faced and an informed consent. In addition, this study was approved by the ethics committee of the POLTEKKES Bandung and all procedures were in accordance with the Declaration of Helsinki. The anthropometric characteristics of the subjects are shown in Table 1 .

Table 1. Anthropometric characteristics of three teams

\begin{tabular}{lccc}
\hline \multicolumn{1}{c}{ Variables } & $\begin{array}{c}\text { Team } \mathbf{A} \\
\mathbf{x} \pm \mathbf{S D}\end{array}$ & $\begin{array}{c}\text { Team B } \\
\mathbf{x} \pm \mathbf{S D}\end{array}$ & $\begin{array}{c}\text { Team C } \\
\mathbf{x} \pm \mathbf{S D}\end{array}$ \\
\hline Age (years) & $19.2 \pm 0.50$ & $18.7 \pm 0.50$ & $19.2 \pm 0.96$ \\
Body mass $(\mathrm{kg})$ & $52.63 \pm 1.86$ & $55.83 \pm 3.44$ & $54.90 \pm 3.70$ \\
Height $(\mathrm{cm})$ & $156.3 \pm 4.35$ & $158.8 \pm 2.63$ & $159.3 \pm 6.60$ \\
BMI $(\mathrm{kg} / \mathrm{m} 2)$ & $21.57 \pm 0.91$ & $21.13 \pm 0.74$ & $21.64 \pm 0.53$ \\
\hline
\end{tabular}

BMI - body mass index, SD - standard deviation

\section{Study organization}

This was an observational study which required all participants to complete one familiarization session and two experimental sessions. During the first session (laboratory test), all players performed a treadmill test for $\mathrm{VO}_{2}$ max and the running-based anaerobic sprint test (RAST) for measuring anaerobic performance. Both tests were separated by an interval of at least 3 days for recovery. For the second session (on-court test), the participants played a simulated match on court, according to the current rules of Fédération Internationale de Football Association (FIFA) (https://www. fifa.com/mensyoutholympic/news/the-rules-of-futsal-explained). Furthermore, the blood lactate concentration and RPE were assessed in the pre and post-test in both sessions which was separated by a week for recovery. Participants were allowed and encouraged to drink enough mineral water ad libitum in other to remain hydrated after the last task in each session. In this study, the players considered for analysis were those at the defender $(n=3)$, left-winger $(n=3)$, rightwinger $(n=3)$ and pivot $(n=3)$ positions, excluding goalkeepers $(n=3)$. The research design is illustrated in Figure 1.

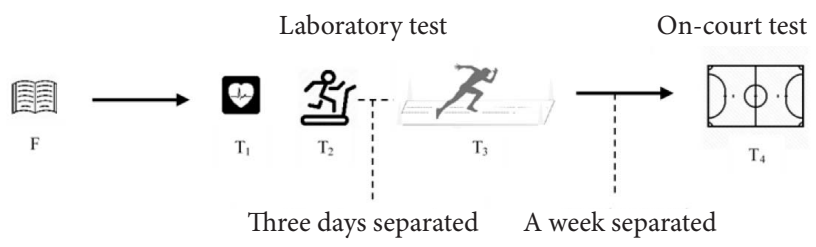

Fig. 1. The research designs: $F=$ familiarization session, $\mathrm{T}_{1}=$ Anthropometry assessments, $\mathrm{T}_{2}=\mathrm{VO}_{2}$ max test, $\mathrm{T}_{3}=$ RAST test, $\mathrm{T}_{4}=$ Match exhibition

\section{Laboratory}

A week after a familiarization session, laboratory assessments were carried out on participants. Before the commencement of the test, they were instructed to take a light dinner (before 9:00 p.m.) a day before and not to eat food or drink caffeine beverages on the test day. For the first laborato- 
ry measurements, anthropometric characteristics were measured using the Omron HBF-375 Karada Scan Body Composition Scale, which assess the percentage of body weight and fat of all participants. The stadiometer with $0.1 \mathrm{~cm}$ readability (Seca 214 Portable Stadiometer, Cardinal Health, Ohio, USA) was used to measure body height. Furthermore, Body mass index was calculated as the ratio of body mass (kilograms), to the square of body height (metres).

After the anthropometric measurements, a $100 \mu \mathrm{L}$ sample of fingertip capillary blood was obtained from each player to measure for lactate, using the Lactate Pro analyzer (Arkray, Shiga, Japan). An hour prior to $\mathrm{VO}_{2}$ max testing, all participants completed the Electro Cardio Graph (ECG) to monitor their cardiac normalities. After receiving health declaration based on ECG assessments, they continued with the $\mathrm{VO}_{2}$ max assessments. Prior to $\mathrm{VO}_{2}$ max test, they were required to perform warm-ups $\left(6 \mathrm{~min}\right.$ jog at $\left.6.8 \mathrm{~km} \cdot \mathrm{h}^{-1}\right)$. The $\mathrm{VO}_{2}$ max test began at approximately 10:00 a.m indoors with a temperature range between $23-25{ }^{\circ} \mathrm{C}$ and relative humidity $65-75 \%$. A treadmill cardio pulmonary exercise test Quark CPET T170, was used to measure th $\mathrm{VO}_{2}$ max of each participant, with a velocity dependent ramp test (INCS) incremental protocols, at constant inclination $\left(0^{\circ}\right)$ and increasing speed $\left(0.5 \mathrm{~km} \cdot \mathrm{h}^{-1}\right.$ every $30 \mathrm{~s}$ from the initial $\left.12.0 \mathrm{~km} \cdot \mathrm{h}^{-1}\right)$. $\mathrm{VO}_{2}$ max is defined as the plateau attained from by the relationship between $\mathrm{VO}_{2}$ and running speed therefore, participants were verbally encouraged until volitional exhaustion. The heart rate (HR) was continuously monitored with a test employing a Polar V800 GPS during the $\mathrm{VO}_{2}$ max test. At the end of the last task, the lactate was measured immediately after the $\mathrm{VO}_{2}$ max test, followed by the determination of the rate of perceived exertion (RPE) using CR-10 scale as described by previous study (Arney et al., 2019).

Three days after the last tasks of $\mathrm{VO}_{2}$ max test measurement, the RAST test was performed. The protocols and formula calculation of the RAST test were based on previous studies (Zagatto, WR, \& CA, 2009). The RAST test was carried out by following a number of stages: (i) The participant was ready in a "standing start position" at one end of the $35 \mathrm{~m}$ sprint track (i.e. cone A) (ii) The second test administrator performed a countdown to the start of the test (iii) On the "GO" signal, the participant performed a sprint with maximal effort to the end of the $35 \mathrm{~m}$ track (i.e. cone B) (iv) Upon crossing the $35 \mathrm{~m}$ line, the second test administrator (standing on the end line) screamed "CLEAR". Subsequently, the first test administrator began the 10 secs recovery period countdown using a stopwatch (Seiko Stopwatch S23601P) (v) During the recovery period, the participant was getting ready to perform another $35 \mathrm{~m}$ sprint back to the start position (vi) All participants repeated this procedure for six sprints (five $10 \mathrm{sec}$ recovery periods). (vii) To minimize any problems after the last task of the RAST test, they were to rest, either by sitting or standing. The running time of the sprints was recorded using a beam photocell system (Microgate, Bolzano, Italy). In addition, pre and post-testing of blood lactate and RPE measurements in the RAST test were carried out in the same way as that of the $\mathrm{VO}_{2}$ max test.

\section{On-court test}

A week after the last day of the RAST test, on-court test was carried out in the Saraga Futsal Arena Bandung. Three matches were played according to the current rules of FIFA which began at 5.00 p.m., with a warm weather $\left(22-23{ }^{\circ} \mathrm{C}\right)$ and relative humidity (65-75\%). To ensure that players were highly motivated, a one-off match exhibition was included and the opponent was the main rival of Bandung district female futsal club. Meanwhile, all matches were performed under the supervision, tactical and motivation of head coaches in order to keep running euphoria and performance of players high. For the match exhibition, 5 female players consisting of a goalkeeper $(n=1)$, left-winger $(n=1)$, right-winger $(n=1)$ and pivot $(n=1)$ were randomly picked and assigned to team A. Furthermore, with the same amount and composition, other players were assigned to team $\mathrm{B}$ and $\mathrm{C}$, respectively (match design is displayed in Figure 2). Specifically, all teams played without the opportunity to carry out substitutions. The Polar V800 GPS was used to monitored Heart Rate (HR) intensity during the match.

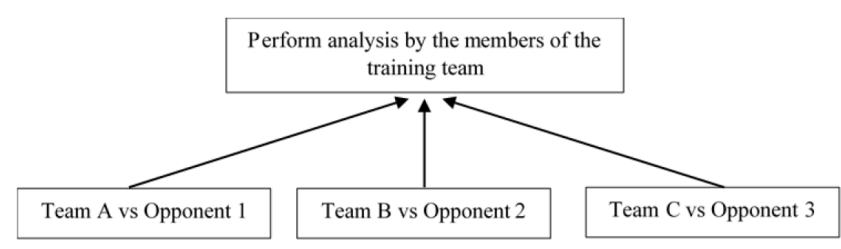

Fig. 2. The head to head futsal match designs

During futsal match exhibition, one video camera (Handycam Canon LEGRIA FS200) was mounted $5 \mathrm{~m}$ behind the baseline and $8 \mathrm{~m}$ above the ground at the same end of each court to film each match. Furthermore, the film from each match was used to assess the performance analysis. The video used technical assessment was developed by expert members of the training team $(n=5)$, with more 10 years of experience in futsal. The performance analysis of the match was carried out as follows: (i) successful passing, when a player in possession of the ball is able to send it to a teammate, (ii) failed passing, when a player is unable to make a reasonable attempt at playing a pass to a teammate, (iii) shot on target, a clear attempt to score that would have entered the net but was either saved by the goalkeeper or stopped by a player who is the last-man with the goalkeeper having no chance of preventing the goal (last line block), (iv) shot off target, any shot that goes over or wide off the goal area without making contact with another player, would have gone over or wide off the goal but was either saved by a goalkeeper or stopped by an outfield player, or directly hits the frame of the goal post (v) tackling, when a player not in possession of the ball engages with an opponent in possession of the ball and legally uses a foot to take the ball away, and (vi) heading, when a player uses the head to hit the ball in other for it to move in a certain direction.

\section{Statistical analysis}

The statistical analysis tests were performed with the SPSS software, V.21.0, while the normal distribution of the sample was checked by using the Shapiro-Wilk test. The repeated measurement and Post-hoc LSD were used to evaluate aerobic and anaerobic performance, HR and RPE in each group. Furthermore, the $95 \%$ confidence intervals and 
change percentages were calculated. Statistical significance was accepted at the $\mathrm{p}<0.05$ level as indicated by the SPSS software, V.21.0.

\section{Results}

Table 2 shows the results for the aerobic and anaerobic performance during the $\mathrm{INC}_{\mathrm{S}}$ and RAST tests, respectively. Table 3 depicts the results from the measurement of the lactate and RPE in the CWT and SJR groups. Table 4 displays the average characteristics for the different performance (shooting, tackling, heading and passing) in the three exhibition futsal matches. Additionally, Figure 3 shows the average heart rate during matches for the 3 teams.

\section{Aerobic and anaerobic performance}

Regarding aerobic capacity, there were no significant differences in the average $\mathrm{VO}_{2}$ max obtained for the 3 teams $(\mathrm{p}=0.531)$. Furthermore, for the anaerobic performance, Analysis of Variance (ANOVA) revealed no significant difference for the mean power (MP) and fatigue index (FI) ( $\mathrm{p}=0.425, \mathrm{p}=0.938$, respectively) although, the MP and FI of team $\mathrm{C}$ was low compared to $\mathrm{A}$ and $\mathrm{B}$.

Table 2. $\mathrm{VO}_{2} \max , \mathrm{MP}$ and FI during the INCS and RAST tests in elite professional futsal players.

\begin{tabular}{|c|c|c|c|}
\hline Group & $\begin{array}{c}\mathrm{VO}_{2} \mathbf{m a x} \\
\left(\mathbf{m l} \cdot \mathbf{k g}^{-1} \cdot \mathbf{m i n}^{-1}\right)\end{array}$ & $\begin{array}{c}\text { MP } \\
\text { (watts) }\end{array}$ & $\begin{array}{c}\text { FI } \\
\text { (watts/second) }\end{array}$ \\
\hline Team A & $40.08 \pm 0.84$ & $1813.25 \pm 344.43$ & $1.03 \pm 1.02$ \\
\hline Team B & $40.73 \pm 0.77$ & $1970.25 \pm 222.56$ & $0.87 \pm 0.84$ \\
\hline Team C & $40.33 \pm 0.78$ & $1720.50 \pm 186.64$ & $0.80 \pm 0.98$ \\
\hline$p$-value & 0.531 & 0.425 & 0.938 \\
\hline
\end{tabular}

MP - mean power, FI - fatigue index. The values are presented as mean $\pm S D$.

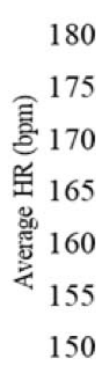

Team A

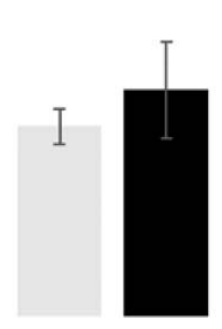

Team B
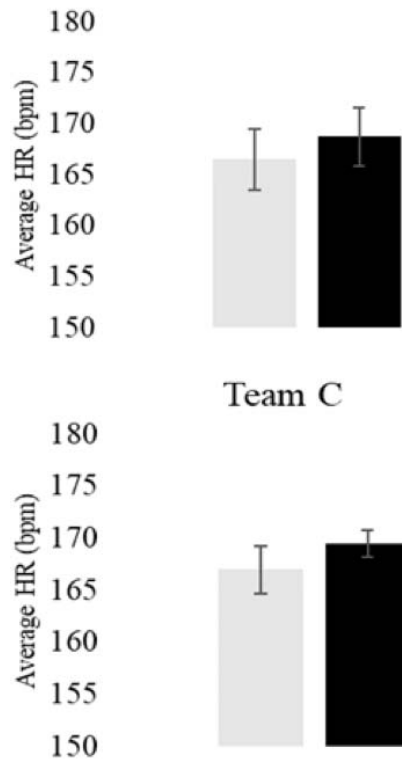

Team C
First half

- Second half

First half

- Second half

Fig. 3. Average HR of three group during futsal matches

Table 3. Difference changes in lactate measures in three groups

\begin{tabular}{|c|c|c|c|c|c|c|}
\hline Group & $\underset{(\mathrm{mmol} / \mathrm{l})}{\text { Lactate-pre }^{1}}$ & $\underset{(\mathrm{mmol} / \mathrm{I})}{\text { Lactate-post }^{1}}$ & $\mathrm{RPE}^{1}$ & $\underset{(\mathrm{mmol} / \mathrm{l})}{\text { Lactate-pre }^{2}}$ & $\underset{(\mathrm{mmol} / \mathrm{l})}{\text { Lactate-post }^{2}}$ & $\mathrm{RPE}^{2}$ \\
\hline Team A & $1.73 \pm 0.33$ & $11.58 \pm 0.62$ & $9.75 \pm 0.50$ & $1.93 \pm 0.92$ & $8.23 \pm 0.63$ & $8.50 \pm 0.58$ \\
\hline Team B & $1.38 \pm 0.59$ & $12.25 \pm 0.70$ & $9.00 \pm 0.82$ & $1.70 \pm 0.44$ & $8.23 \pm 0.88$ & $8.00 \pm 0.82$ \\
\hline Team C & $2.00 \pm 0.89$ & $11.95 \pm 0.91$ & $9.72 \pm 0.50$ & $1.58 \pm 0.74$ & $7.70 \pm 0.88$ & $8.50 \pm 1.29$ \\
\hline$p$-value & 0.422 & 0.476 & 0.201 & 0.792 & 0.587 & 0.698 \\
\hline
\end{tabular}

${ }^{1}$ Lactate-pre - blood lactate response before INCS test, ${ }^{1}$ Lactate-post - blood lactate response after INCS test, ${ }^{1} \mathrm{RPE}$ - rating of perceived exertion after INCS test, ${ }^{2}$ Lactate-pre - blood lactate response before RAST test, ${ }^{2}$ Lactate-post - blood lactate response after RAST test, ${ }^{2} \mathrm{RPE}$ - rating of perceived exertion after RAST test. The values are presented as mean \pm SD.

Table 4. The distribution of the performance characteristics of three exhibition futsal matches

\begin{tabular}{|c|c|c|c|c|c|c|}
\hline Team & Success Passing & Failed Passing & Shot on Target & Shot of Target & Tackling & Heading \\
\hline A & 160 & 25 & 15 & 8 & 1 & 3 \\
\hline B & 181 & 20 & 18 & 13 & 2 & 2 \\
\hline $\mathrm{C}$ & 154 & 30 & 12 & 14 & 1 & 3 \\
\hline
\end{tabular}

Data as a mean total of the performance in each team 


\section{Blood lactate concentration and RPE}

For the 3 teams, lactate concentration increased from pre to post-test in each session's test (INCS and RAST). Furthermore, ANOVA revealed no significant difference in lactate concentration at the pre-test for both sessions $(p=0.422$, $\mathrm{p}=0.792$, respectively). It also revealed no significant difference in the lactate parameter post-test for both sessions $(\mathrm{p}=0.476, \mathrm{p}=0.587$, respectively). With reference to the RPE for all participants after the INCS and RAST tests, ANOVA revealed no significant difference among the 3 teams $(p=0.201$ and $\mathrm{p}=0.698$, respectively).

\section{On-court test}

The team of analysts revealed that team $C$ were less successful in passing and shot on target compared to B and $\mathrm{A}$ (for successful passes $=154$ vs 181 vs 160 , for shot on target $=12$ vs 18 vs15). Conversationally, the total failed passes and shot off target of team $C$ was frequent compared to $B$ and A (for failed passes $=30$ vs 20 vs 25 , for shot off target 14 vs 13 vs 8 ). There was no significant difference in total of tackling and heading for each team during the matches.

\section{Discussion}

The purpose of the study was firstly, to examine the anaerobic and aerobic performance of Indonesian professional female futsal players and secondly, to determine the influence of the anaerobic performance on specific movements (shooting, tackling, heading and passing) in a match-play. To the best knowledge of the authors, this is the first study which assessed both anaerobic and aerobic performance on shooting, tackling, heading and passing. The main discoveries of this study were: (1) determination of the average anaerobic and aerobic performance of Indonesian professional female futsal athletes and (2) determination of the influence of MP and FI on shooting, tackling, heading and passing. These discoveries added to the scientific study that supports the use of physiological characteristics as a formula to determine training regimens used by coaches, sports scientists and female futsal players.

According to previous studies, $\mathrm{VO}_{2}$ max is the maximal oxygen transport from the environment to the mitochondria which supports the oxidative production of ATP for carrying out physical work (Levine, 2008). Therefore, $\mathrm{VO}_{2}$ max is a crucial physiological aspect which futsal players should improve on (Alvarez, D’Ottavio, Vera, \& Castagna, 2009; Ayarra, Nakamura, Iturricastillo, Castillo, \& Yanci, 2018; Naser et al., 2017). This study has been confirmed by Tomlin et al. (2002), which explained that $\mathrm{VO}_{2}$ max is needed for inducing quicker recovery (e.g. improved Phosphocreatine (PCr) recovery) between high-intense efforts or even after exhaustion. In this study, the average $\mathrm{VO}_{2}$ max of Indonesian professional female futsal players was $40.04 \pm 0.04 \mathrm{ml} \cdot \mathrm{kg}^{-1} \cdot \mathrm{min}^{-1}$ (the average of the 3 teams). These values were considerably low compared to those in previous studies (Barbero-Alvarez et al., 2015; Datson et al., 2014; Haugen, Tonnessen, Hem, Leirstein, \& Seiler, 2014; Krustrup, Mohr, Ellingsgaard, \& Bangsbo, 2005). For example, Barbero-Alvarez et al. (2015) examined the $\mathrm{VO}_{2}$ max of fourteen female futsal players from the Venezuelan National team, using the treadmill running test and obtained $\mathrm{VO}_{2}$ max values of $45.3 \pm 5.6 \mathrm{ml} \cdot \mathrm{kg}^{-1} \cdot \mathrm{min}^{-1}$. Responding to these differences in existing literatures, it was revealed that genetics and differences in level of training or competition may be considered as explanatory factors (Manzi, Iellamo, Impellizzeri, D’Ottavio, \& Castagna, 2009; Perrier-Melo, Figueira, Guimarães, \& Costa, 2018).

In this study, the RAST test was applied as a method to measure the anaerobic performance of participants. According to previous studies, it is a method that assesses the anaerobic power and capacity by measuring the peak power, MP and FI variables (Keir, Thériault, \& Serresse, 2013; Zagatto et al., 2009). Specifically, Zagatto al. (2009), explained that the MP in the RAST test indicates a player's ability to maintain anaerobic performance over time (high score indicates a better ability), while FI variables indicates the rate at which power declines for a player i.e. the lower the FI value, the higher the ability to maintain anaerobic performance and vice versa. In this study, the average MP and FI value of team $\mathrm{C}$ was lower compared to A and B (see Table 2). Although, there were some difficulties in the discovery of supportive studies related to the anaerobic performance of futsal female players using RAST test. However, this study was able to show the importance of anaerobic capacity on performance. According to some previous studies, anaerobic actions are involved in the explosive movements in futsal (e.g. kicking, tackling, heading and sprinting) (Beato et al., 2017; Naser et al., 2017). Furthermore, an excellent anaerobic capacity is needed to improve the performance of these movements (Beato et al., 2017; Naser et al., 2017). In line with these studies, the results obtained in this study were strong associations between anaerobic capacity and explosive movements. This is evident from the fact that the average MP and FI values of team $\mathrm{C}$ were lower compared to the other teams. On careful analyzation, it was discovered that team $\mathrm{C}$ was less successful in making passes and shots on target (see Table 4). Furthermore, the results of this study clarified that excellent anaerobic capacity are needed to support explosive movement performance.

However, this study is not without limitations. Firstly, the physical, role-related and emotional functioning, including differences in the lifestyles of the participants could have an impact on the obtained results. Secondly, future studies should be concerned with the correlation statistical analysis (e.g. Pearson correlation coefficient) to measure the relationship between anaerobic capacity and explosive movements. More or less, this study is expected to assist coaches to improve the performance of players from the perspective of physiological characteristics of female futsal players.

\section{Conclusions}

The results of this study provided evidence and demonstrated strong associations between anaerobic capacity and explosive movements (shooting, tackling, heading, and passing) among female futsal players. Therefore, the highintensity interval training method should preferably be used by coaches and players to improve anaerobic capacity.

\section{Acknowledgement}

The authors express gratitude to the study institutions and community service (LPPM) ITB Indonesia who supported and funded the project. 


\section{Conflict of interest}

The authors state no conflict of interest.

\section{References}

Chandra, S. (2013). in Indonesia, 67(December), 37-41.

Beato, M., Coratella, G., Schena, F., \& Hulton, A. T. (2017). Evaluation of the external \& internal workload in female futsal players. Biology of Sport, 34(3), 227-231. https://doi.org/10.5114/biolsport.2017.65998

Ayala, F., Sainz de Baranda, P., De Ste Croix, M., \& Santonja, F. (2011). Criterion-related validity of four clinical tests used to measure hamstring flexibility in professional futsal players. Physical Therapy in Sport, 12(4), 175-181. https://doi.org/10.1016/j.ptsp.2011.02.005

Farid Farhani, Hamid Rajabi, Raoof Negaresh, Ajmol Ali, Sadegh Amani Shalamzari, \& Julien S. Baker (2019). Reliability and Validity of a Novel Futsal Special Performance Test Designed to Measure Skills and Anaerobic Performance. International Journal of Sports Physiology and Performance, 14(8), 1096-1102. https://doi.org/10.1123/ijspp.2018-0850

CF, W., FAP, F., FVC, M., AM, L., FY, N., \& SP, W. (2011). Faster and slower post-training recovery in futsal: multifactorial classification of recovery profiles. International Journal, 1-19.

Barbero-Alvarez, J. C., Soto, V. M., Barbero-Alvarez, V., \& Granda-Vera, J. (2008). Match analysis and heart rate of futsal players during competition. Journal of Sports Sciences, 26(1), 63-73.

https://doi.org/10.1080/02640410701287289

Barbero-Alvarez, J. C., Subiela, J. V., Granda-Vera, J., Castagna, C., Gómez, M., \& Del Coso, J. (2015). Aerobic fitness and performance in elite female futsal players. Biology of Sport, 32(4), 339-344. https://doi.org/10.5604/20831862.1189200

Naser, N., Ali, A., \& Macadam, P. (2017). Physical and physiological demands of futsal. Journal of Exercise Science and Fitness, 15(2), 76-80.

https://doi.org/10.1016/j.jesf.2017.09.001

Sales, M., Maciel, A., Aguiar, S., Asano, R., Motta-Santos, D., Moraes, J., ... Sousa, C. (2018). Vertical Jump Is Strongly Associated to Running-Based Anaerobic Sprint Test in Teenage Futsal Male Athletes. Sports, 6(4), 129. https://doi.org/10.3390/sports6040129

Corrêa, U. C., de Pinho, S. T., da Silva, S. L., Clavijo, F. A. R., Souza, T. de O., \& Tani, G. (2016). Revealing the decisionmaking of dribbling in the sport of futsal. Journal of Sports Sciences, 34(24), 2321-2328. https://doi.org/10.1080/02640414.2016.1232488

Castagna, C., D’Ottavio, S., Vera, J. G., \& Álvarez, J. C. B. (2009). Match demands of professional Futsal: A case study. Journal of Science and Medicine in Sport, 12(4), 490-494. https://doi.org/10.1016/j.jsams.2008.02.001

Astagna, C. A. C. (2010). Physiological demands of an intermittent futsal-oriented high-intensity test, 2322-2329.

Lago-Fuentes, C., Rey, E., Padrón-Cabo, A., De Rellán-Guerra, A. S., Fragueiro-Rodríguez, A., \& García-Núñez, J. (2018). Effects of core strength training using stable and unstable surfaces on physical fitness and functional performance in professional female futsal players. Journal of Human Kinetics, 65(1), 213-224. https://doi.org/10.2478/hukin-2018-0029
Ramos-Campo, D. J., Rubio-Arias, J. A., Carrasco-Poyatos, M., \& Alcaraz, P. E. (2016). Physical performance of elite and subelite Spanish female futsal players. Biology of Sport, 33(3), 297-304. https://doi.org/10.5604/20831862.1212633

Arney, B. E., Glover, R., Fusco, A., Cortis, C., de Koning, J. J., van Erp, T., ... Foster, C. (2019). Comparison Of RPE Rating Scales For Session RPE. Medicine \& Science in Sports \& Exercise, 51(Supplement), 920-921. https://doi.org/10.1249/01.mss.0000563258.44197.66

Zagatto, A. M., Beck, W. R., \& Gobatto, C. A. (2009). Validity of the Running Anaerobic Sprint Test for Assessing Anaerobic Power and Predicting Short-Distance Performances. Journal of Strength and Conditioning Research, 23(6), 1820-1827. https://doi.org/10.1519/JSC.0b013e3181b3df32

Levine, B. D. (2008). VO2: What do we know, and what do we still need to know? Journal of Physiology, 586(1), 25-34. https://doi.org/10.1113/jphysiol.2007.147629

Alvarez, J., D’Ottavio, S., Vera, J., \& Castagna, C. (2009). Aerobic Fitness in Futsal Players of Different Competitive Level. Journal of Strength and Conditioning Research, 23(7), 2163-2166. https://doi.org/10.1519/JSC.0b013e3181b7f8ad

Ayarra, R., Nakamura, F. Y., Iturricastillo, A., Castillo, D., \& Yanci, J. (2018). Differences in Physical Performance According to the Competitive Level in Futsal Players. Journal of Human Kinetics, 64(1), 275-285. https://doi.org/10.1515/hukin-2017-0201

Tomlin, D., \& Wenger, H. (2002). The relationships between aerobic fitness, power maintenance and oxygen consumption during intense intermittent exercise. Journal of Science and Medicine in Sport, 5(3), 194-203. https://doi.org/10.1016/S1440-2440(02)80004-4

Datson, N., Hulton, A., Andersson, H., Lewis, T., Weston, M., Drust, B., \& Gregson, W. (2014). Applied physiology of female soccer: An update. Sports Medicine, 44(9), 12251240. https://doi.org/10.1007/s40279-014-0199-1

Haugen, T., Tonnessen, E., Hem, E., Leirstein, S., \& Seiler, S. (2014). $\mathrm{VO}_{2}$ max Characteristics of Elite Female Soccer Players, 1989-2007. International Journal of Sports Physiology and Performance, 9(3), 515-521. https://doi.org/10.1123/ijspp.2012-0150

Krustrup, P., Mohr, M., Ellingsgaard, H., \& Bangsbo, J. (2005). Physical demands during an elite female soccer game: Importance of training status. Medicine and Science in Sports and Exercise, 37(7), 1242-1248. https://doi.org/10.1249/01.mss.0000170062.73981.94

Manzi, V., Iellamo, F., Impellizzeri, F., D’Ottavio, S., \& Castagna, C. (2009). Relation between individualized training impulses and performance in distance runners. Medicine and Science in Sports and Exercise, 41(11), 2090-2096. https://doi.org/10.1249/MSS.0b013e3181a6a959

Perrier-Melo, R. J., Figueira, F. A. M. dos S., Guimarães, G. V., \& Costa, M. da C. (2018). High-intensity interval training in heart transplant recipients: A systematic review with metaanalysis. Arquivos Brasileiros de Cardiologia, 110(2), 188194. https://doi.org/10.5935/abc.20180017

Keir, D. A., Thériault, F., \& Serresse, O. (2013). Evaluation of the running-based anaerobic sprint test as a measure of repeated sprint ability in collegiate-level soccer players. Journal of Strength and Conditioning Research, 27(6), 1671-1678. https://doi.org/10.1519/JSC.0b013e31827367ba 


\title{
ФІЗІОЛОГІЧНІ ТА КОНКУРЕНТНІ ХАРАКТЕРИСТИКИ ПРОФЕСІЙНИХ ГРАВЦІВ ФУТЗАЛУ У ЖІНОК
}

\author{
Томмі Апріантоно ${ }^{1 \mathrm{ABC}}$, Самсул Бахрі ${ }^{1 \mathrm{BC}}$, Шрі Іхсані Індах ${ }^{1 \mathrm{BC}}$, Віната Багус $^{1 \mathrm{DE}}$ \\ ${ }^{1}$ Інститут технологій Бандунг \\ Авторський вклад: А - дизайн дослідження; В - збір даних; C - статаналіз; D - підготовка рукопису; Е - збір коштів \\ Реферат. Стаття: 7 с., 3 рис., 4 табл., 26 джерел.
}

Метою дослідження було вивчити анаеробну та аеробну ефективність, а також визначити вплив анаеробної продуктивності на конкретні рухи під час матч-гри.

Матеріали та методи. Загалом було набрано 12 індонезійських професійних футболісток із жіночого футзального клубу району Бандунг, які взяли участь у дослідженні. Вони повинні були пройти одне ознайомлення та два експериментальних заняття. Під час першого заняття (лабораторне випробування) всі гравці провели тест на біговій доріжці, щоб визначити свою максимальну норму споживання кисню $\left(\mathrm{VO}_{2} \max \right)$ та анаеробний спринтерський тест на швидкості (RAST) для вимірювання анаеробних показників. На другому занятті (випробування на майданчику) учасники зіграли змодельований матч на корті. Тренерська група 3 5 експертів провела дослідження щодо конкурентних результатів кожного гравця за матч. Крім того, концентрацію лактату в крові та швидкість сприйняття фізичних навантажень (RPE) оцінювали в попередньому та післятестовому проведенні обох сеансів, які були розділені тижнем, щоб гравці змогли відновитись.

Результати. Результати показали, що не було суттєвої різниці між середньою потужністю (MP) та індексом втоми (FI) (p $=0,425, \mathrm{p}=0,938$, відповідно) для анаеробних показників з використанням дисперсійного аналізу (ANOVA), хоча, MP та FI команди С була нижчою порівняно з А та Б. Крім того, загальна кількість невдалих передач та попадання в ціль команди С була більшою порівняно з В та А (для невдалих пасів = 30 проти 20 проти 25, для відбиття цілі 14 проти 13 проти 8).

Висновки. Отримані результати показали, що існують сильні зв'язки між анаеробною здатністю та вибуховими рухами (простріли, боротьба, удар головою та передача) серед гравців жіночого футзалу.

Ключові слова: анаеробна ефективність, спринтерський тест, простріл, командні види спорту, техніка, $\mathrm{VO}_{2} \max$.

\section{Information about the authors:}

Apriantono, Tommy: tommy@fa.itb.ac.id; https://orcid.org/0000-0002-5169-0924; Institut Teknologi Bandung, Department of Sport Science Faculty; Jl. Ganesha No.10, Lb. Siliwangi, Coblong, Kota Bandung, Jawa Barat, 40132, Indonesia.

Bahri, Samsul: samsul@fa.itb.ac.id; https://orcid.org/0000-0002-9281-0750; Institut Teknologi Bandung, Departemen of Sport Science Faculty; Jl. Ganesha No.10, Lb. Siliwangi, Coblong, Kota Bandung, Jawa Barat, 40132, Indonesia.

Indah Ihsani, Sri: sriindah@fa.itb.ac.id; https://orcid.org/0000-0002-3309-5603; Institut Teknologi Bandung, Departemen of Sport Science Faculty; Jl. Ganesha No.10, Lb. Siliwangi, Coblong, Kota Bandung, Jawa Barat, 40132, Indonesia.

Bagus Winata: fransiskusasisibaguswinata@gmail.com; https://orcid.org/0000-0002-9407-163X; Institut Teknologi Bandung, Departemen of Sport Science Faculty; Jalan Jati Raya Rt.002 Rw.008 No 56 Kelurahan Sukamaju, Kecamatan Cilodong, Kota Depok, Jawa Barat, 16415, Indonesia.

Cite this article as: Apriantono, T., Bahri, S., Ihsani Indah, Sri, \& Bagus, W. (2021). Physiological and Competitive Characteristics of Professional Female Futsal Players. Teoriâ ta Metodika Fizičnogo Vihovannâ, 21(1), 19-25. https://doi.org/10.17309/tmfv.2021.1.03

Received: 24.11.2020. Accepted: 20.03.2021. Published: 25.03.2021

This work is licensed under a Creative Commons Attribution 4.0 International License (http://creativecommons.org/licenses/by/4.0). 